\title{
Margaret McCartney: Breaking down the silo walls
}

\author{
Margaret McCartney general practitioner
}

Glasgow

The "silo mentality" in medicine, in which information is kept secret from others in the broader team, is rightly castigated-for example, NHS organisations not sharing data, or separate professional workforces duplicating work without sharing results. Silos need breaking open, but the NHS creates and enforces these working patterns daily.

Take, for example, the worthy campaign to reduce antibiotic prescribing. Quite right: this should lead to fewer drug resistances. But there's also a campaign to recognise and treat potential sepsis earlier-with antibiotics. The two campaigns inevitably conflict.

Or consider the push for patients to be screened. Requiring specific numbers of people to take tests goes against the General Medical Council's requirement that people should make informed choices about tests or treatment.

Also, I attend meetings to discuss alternatives to hospital referrals-yet we GPs are warned that we must refer patients with cancer urgently.

Here are the real silos: structural pushes and pulls by one group working towards its aims will, in effect, conflict with another group. "But no!" they cry: "We don't mean each other any harm. We mean to reduce the amount of inappropriate antibiotics. We don't mean to force screening on anyone. And how dare you suggest that, by encouraging GPs to use resources carefully, we're delaying cancer diagnoses."

Decisions in general practice are often as frequent as our heartbeats. We are calculated risk takers

Often the people in one silo don't know about their opposite numbers, let alone what they're saying or what influence they exert. But GPs do: we have to manage these conflicts every day with our patients. Anyone can become septic from an infection that seems to be low risk and viral but later becomes bacterial and lethal. (And evidence shows that reductions in antibiotic prescriptions are associated with small increases in pneumonia and peritonsillar abscess. ${ }^{1}$ ) We compare our referral rates with those of other practices, but it's impossible to know whether high rates are good or bad-do they represent patient choice or doctors' unnecessary doubt?

Decisions in general practice are often as frequent as our heartbeats. We are calculated risk takers. It's impossible always to make the right call. GPs are used to being judged by specialists and found variously wanting. That's because we exist in among the silos, from which people rarely look out.

It doesn't have to be this way. The time has come for GPs to be authors of their own clinical guidelines, looking to the silos for dialogue and information. We need to accept that good doctors practising good medicine can't be right the whole time. These conflicts are inherent to medicine and can't be broken down; but, with a little more generalism, some of the silo walls could be.

Competing interests: See www.bmj.com/about-bmj/freelancecontributors/margaret-mccartney.

Provenance and peer review: Commissioned; not externally peer reviewed.

Follow Margaret on Twitter, @mgtmccartney

1 Gulliford MC, Moore MV, Little P, et al. Safety of reduced antibiotic prescribing for self limiting respiratory tract infections in primary care: cohort study using electronic health records. BMJ 2016;354:i3410. doi:10.1136/bmj.i3410 pmid:27378578.

Published by the BMJ Publishing Group Limited. For permission to use (where not already granted under a licence) please go to http://group.bmj.com/group/rights-licensing/ permissions 